\title{
8p11.2 deletion syndrome
}

INSERM

\section{Source}

INSERM. (1999). Orphanet: an online rare disease and orphan drug data base. 8 p11.2 deletion syndrome. ORPHA:251066

8p11.2 deletion syndrome is a contiguous gene syndrome characterized by the association of congenital spherocytosis, dysmorphic features, growth delay and hypogonadotropic hypogonadism. 